\title{
Strategi Pelayanan Prima Kelompok Bimbingan Ibadah Haji terhadap Calon Jamaah dalam Meningkatkan Bimbingan Kualitas Ibadah Haji
}

\author{
Pusti Lestari $^{1^{*}}$, Dadang Kuswana ${ }^{2}, \boldsymbol{\&}$ Yuliani $^{1}$ \\ 1 Jurusan Manajemen Dakwah, UIN Sunan Gunung Djati, Bandung \\ ${ }^{2}$ Jurusan Pengembangan Masyarakat Islam, UIN Sunan Gunung Djati, Bandung \\ *Email:pusti.lestari@student.uinsgd.ac.id
}

\begin{abstract}
ABSTRAK
Tujuan penelitian mengungkapkan konsep pelayanan prima, rancangan pemberian pelayanan, dan bentuk pelayanan KBIH Maqdis terhadap jamaah dalam meningkatkan kualitas bimbingan ibadah haji. Metode yang digunakan dalam penelitian ini adalah metode deskriptif dengan pendekatan kualitatif. Adapun langkah-langkah penelitian yang ditempuh; penentuan lokasi penelitian, pengumpulan data dengan menggunakan teknik observasi, wawancara, studi kepustakaan, dokumentasi. Dari hasil penelitian disimpulkan bahwa konsep pelayanan prima KBIH Maqdis dalam meningkatkan kualitas bimbingan ibadah haji dilihat dari konsep pelayanan prima yang diterapkan KBIH Maqdis meliputi: kemampuan, sikap, penampilan, perhatian, tindakan dan tanggungjawab. Kemudian rancangan pemberian pelayanan prima KBIH Maqdis diantaranya: regulasi layanan, fasilitas layanan, peranan tim pengarah dan budaya pemberian pelayanan. Selain itu bentuk layanan KBIH Maqdis terhadap jamaah dalam meningkatkan kualitas bimbingan ibadah haji diantaranya KBIH Maqdis menyediakan pembimbing haji yang profesional dan materi bimbingan ibadah haji.
\end{abstract}

Kata Kunci: Strategi; Pelayanan Prima; Kualitas: Bimbingan

\section{ABSTRACT}

The purpose of this study is to determine the concept of excellent service, the design of service delivery, and the form of KBIH Maqdis service to the congregation in improving the quality of pilgrimage guidance. The method used in this research is descriptive method with qualitative approach. The research steps taken; determination of research location, data collection by using observation technique, interview, literature study, further documentation of data analysis by means of data reduction, data classification and drawing conclusion. From the result of the research, it is concluded that the concept of excellent service of KBIH Maqdis in improving the quality of Haij guidance from the concept of excellent service applied by KBIH Maqdis include: ability, attitude, appearance, attention, action and responsibility. Then the design of service delivery prime KBIH Maqdis include: service regulation, service facility, role of steering team and culture of service delivery. In addition, the form of KBIH Maqdis service to pilgrims in improving 
Strategi Pelayanan Prima Kelompok Bimbingan Ibadah Haji...

the quality of haj pilgrimage services such as KBIH Maqdis provides professional hajj guide and pilgrimage guidance material.

Keywords: Strategy; Excellent Service; Quality; Guidance.

\section{PENDAHULUAN}

Ibadah haji adalah rukun Islam kelima.Secara bahasa, haji berarti al-qashd (bermaksud) adalah pergi mengunjungi tempat yang diagungkan. Sementara secara istilah, haji bermaksud mendatangi Baitullah untuk amal ibadah tertentu yang dilakukan pada waktu dan cara yang tertentu juga. Dasar hukum haji Para ulama fiqih sepakat bahwa ibadah haji dan umrah adalah wajib hukumnya bagi setiap muslim yang mempunyai kemampuan biaya, fisik dan waktu.

Kewajiban untuk berhaji, minimal sekali dalam seumur hidup itu, dibebankan hanya kepada seorang muslim yang mampu dalam arti luas, yaitu mampu secara jasmani maupun rohani. Selain itu, "mampu" berarti juga mampu secara finansial, dalam arti memiliki dana yang diperlukan untuk menjalankan ibadah haji yang dilaksanakan ditempat jauh. Sebab hal tersebut, ibadah haji bisa dikatakan ibadah yang unique. Tidak semata bentuk ritualnya itu sendiri, tetapi seperti dapat disarikan dari Encyclopedia van Nederlandsch Indie, pelaksanaan ibadah ini melibatkan unsur-unsur lain di luar aspek ritual agar pelaksanaannya dapat berjalan dengan baik, sehingga seseorang akan pulang dengan predikat haji mabrur. Dengan kata lain unsur-unsur diluar ritual ibadah haji yang menunjang suksesnya pelaksanaan rukun Islam kelima itu tidak boleh dikesampingkan sedikitpun.

Nidjam dan Hanan menjelaskan, terdapat enam unsur pokok dalam penyelenggaraan ibadah haji yang harus diperhatikan: pertama, calon haji; kedua, pembiayaan; ketiga, administratif: keempat, sarana transportasi; kelima, hubungan bilateral antarnegara; keenam, organisasi pelaksana. Keenam unsur tersebut saling berkelindan satu sama lain di mana keenamnya mempersyaratkan jaminan dalam penyelenggaraan ibadah haji yang berkaitan dengan: pertama, jemaah haji yang telah terdaftar sah dan memenuhi syarat dapat diberangkatkan ke Arab Saudi; kedua, seluruh jemaah haji yang telah berada di tanah suci dapat memenuhi akomodasi, konsumsi dan transportasi; ketiga, seluruh jemaah haji yang telah berada di tanah suci dapat menjalankan ibadah wukuf di Arafah dan rukun haji lainnya; dan keempat, jemaah haji yang telah menunaikan ibadah haji seluruhnya dapat dipulangkan ke daerah asal dengan selamat (Syaukani, 2009:1).

Indonesia mempunyai jumlah penduduk Islam terbesar di dunia sehingga penyelenggaraan ibadah haji telah lama menjadi bagian dari tugas negara berlandaskan pada Undang-Undang RI Nomor 13 Tahun 2008 tentang penyelenggaraan ibadah haji dan Peraturan Pemerintah Nomor 79 Tahun 2012 tentang Penyelenggaraan Haji.

Mayoritas penduduk Indonesia beragama Islam dengan jumlah 87,18\% dari 237.641.326 penduduk Indonesia berdasarkan hasil Sensus Penduduk 2010. Khususnya pemeluk agama Islam di Jawa Barat 4.607.713, Katholik 152.148, dan 
Pusti Lestari, Dadang Kuswana, \& Yuliani

Protestan 55.327(Pusdalisbang Jawa Barat: 2015).

Kuota haji setiap tahunnya bertambah pesat, Tim Informasi Direktorat Jenderal Peyelenggaraan Haji dan Umrah merilis rekam jejak perjalanan ibadah haji di Indonesia. Pada tahun 2010 berjumlah 196206 orang, 2011 - 199848 orang, 2012 - 192290 orang, 2013 - 154547 orang, 2014 - 154467 orang. Khusus pada tahun 2013-2014 sedang renovasi dan pengembangan Masjidil Haram oleh Pemerintah Kerajaan Arab Saudi, mengakibatkan berkurangnya kapasitas daya tampung tempat tawaf, yang sebelumnya 48.000 jemaah per jam menjadi 22.000 jemaah per jam.

Sekretaris Jendral Kementerian Agama Republik Indonesia Nur Syam menyatakan, pada musim haji 2016 kuota haji Indonesia kembali pada angka 211 ribu orang jamaah (Kemenag, Kuota Haji Indonesia, 2015).

Dalam sejarahnya, ibadah haji kemudian melibatkan banyak pihak atau stakeholder, misalnya agen perjalanan, koordinasi antarpemerintah, hubungan antarnegara, perusahaan katering, hotel, pembimbing haji, dan lain-lain. Alhasil, haji bukan saja menyangkut hal-hal yang bersifat religius, melainkan juga bersinggungan dengan persoalan lain termasuk bisnis dan ekonomi (Ikhwan, 2008: 126).

Substansial haji merupakan bagian dari ritual keagamaan kaum muslim yang bersifat personal. Meskipun demikain, sepanjang sejarahnya ibadah haji selalu mendapatkan perhatian negara. Sehingga calon jamaah haji yaitu Warga Negara Indonesia beragam Islam yang akan mendaftarkan diri untuk menunaikan ibadah haji sesuai dengan persyaratan yang ditetapkan.

Kelompok bimbingan ibadah haji $(\mathrm{KBIH})$ merupakan salah satu organisasi dakwah yang bertugas untuk membantu proses pelayanan ibadah haji di Indonesia. KBIH merupakan lembaga atau yayasan sosial Islam dan pemerintah bergerak di bidang bimbingan manasik haji terhadap calon jamaah haji baik selama dalam pembekalan di tanah air maupun pada saat pelaksanaan ibadah haji di Arab Saudi. KBIH sebagai lembaga sosial keagamaan (non pemerintah) telah memiliki legalitas pembimbing melalui undang-undang (Aziz,2007:17).

Pelayanan diartikan sebagai tindakan atau perbuatan seseorang atau organisasi untuk memberikan kepuasan kepada pelanggan atau nasabah (Kamsir,2005:67). Pelayanan sering disebut sebagai jasa yang diberikan oleh perusahaan, artinya bahwa adanya suatu perbuatan yang dilaksanakan sutu pihak terhadap pihak lain. Pelayanan dapat diartikan suatu aktifitas yang bermanfaat yang diberikan oleh satu atau beberapa pihak kepada pihak lain untuk dapat memuaskan kebutuhan dan keinginan yang pada dasarnya bersifat tidak berwujud dan tidak akan menimbulkan kepemilikan apapun (Kottler,1994:446).

Dengan adanya strategi pelayanan prima yang diterapkan di $\mathrm{KBIH}$ diharapkan akan menjadi tolak ukur meningkatkan kualitas pelayanan terhadap jamaah baik kualitas secara rohani dan jasmani. Secara rohani jamaah mampu melaksanakan ibadah haji dengan khusyu' dengan gelar haji mabrur, adapun kualitas secara jasamani yaitu jamaah mendapatkan pelayanan yang baik dari mulai 
pembinaan manasik haji, pemberangkatan, perpulang haji serta pascahaji.

KBIH MAQDIS sebagai penyelenggara kelompok bimbingan ibadah haji yang berdiri sejak 2001 yang terakreditasi A. KBIH Maqdis memiliki citra yang baik di masyarakat terbukti sampai sekarang signifikan dalam memberangkatkan jamaahnya. Pertumbuhan jamaah pada angkatan I mendapat respon yang baik dari calon jamaah sehingga kBIH Maqdis memberangkatkan 35 orang jamaah.Seiring berjalannya waktu KBIH Maqdis setiap tahun memberangkatkan jamaah haji.Pertumbuhan jamaah angkatan 10 dan angkatan $11 \mathrm{KBIH}$ Maqdis memberangkatkan 91 orang jamaah secara konsisten.

Manasik haji gratis yang diselenggarakan KBIH Maqdis merupakan salah satu pelayanan prima yang ditawarkan kepada para calon jamaah. Respon masyarakat terhadap KBIH Maqdis sangat baik, serta manasik haji yang diselenggarakan selalu banyak diikuti oleh para calon jamaah haji dari berbagai kalangan. Adapun pelayanan lainnya yang menjadi program unggulan dari $\mathrm{KBIH}$ Maqdis yaitu tahsin interaktif selama manasik.

Penelitian ini dilakukan di KBIH MAQDIS yang berada di Jl. Soekarno Hatta No.590 MIM (Metro Indah Mall) Blok D-20, Kota Bandung.Penentuan lokasi ini dipilih sebagai tempat penelitian didasarkan atas pertimbangan bahawa lokasi cukup tersedia berbagai data yang dibutuhkan untuk kepentingan penelitian, serta lokasinya strategis sekitar wilayah Bandung dalam mengefektifkan waktu penelitian.

Berdasarkan pada latar belakang masalah yang telah diuraikan di atas, maka masalah pokok yang akan dibahas dalam penelitian ini dirumuskan sebagai beriku: Pertama, bagaimana konsep pelayanan prima KBIH Maqdis yang ditawarkan kepada calon jamaah haji. Kedua, bagaimana rancangan pemberian pelayanan prima di KBIH Maqdis kepada jamaah. Ketiga, bagaimana bentuk pelayanan yang ditawarkan $\mathrm{KBIH}$ Maqdis terhadap calon jamaah haji dalam meningkatkan kualitas ibadah.

Metode yang digunakan dalam penelitian adalah metode deskriptif, untuk memaparkan situasi dan peristiwa. Dengan metode ini dimaksudkan untuk menggambarkan serta menganalisis suatu hasil penelitian tetapi tidak digunakan untuk membuat kesimpulan secara luas karena penulis menjelaskan dan menggambarkan strategi pelayanan prima KBIH Maqdis dalam meningkatkan kualitas bimbingan ibadah haji, yang diharapkan dapat memberikan gambaran secara logis dan sistematis.

Pelayanan prima adalah pelayanan yang memenuhi kebutuhan praktis (practical needs) dan kebutuhan emosional (emotional needs) pelanggan (Rahmayanty, 2013:18). Sementara menurut Endar Sugiarto dalam Daryanto dan Ismanto (2014:131), dikemukakan bahwa falsafah pelayanan prima dalam dunia bisnis, pada hakikatnya pelanggan tidak membeli produk melainkan membeli pelayanan.

Pelaksanan pelayanan prima oleh pihak lembaga/perusahaan terhadap pelanggan, baik itu ditujukkan untuk pelanggan internal maupun eksternal mempunyai peranan yang sangat penting dalam kelangsungan sebuah 
Pusti Lestari, Dadang Kuswana, \& Yuliani

lembaga/perusahaan.Hal ini tergantung dari loyalitas pelanggan kepada lembaga/perusahaan.

Strategi (siasat) adalah termasuk jenis rencana untuk mencapai suatu tujuan yang diinginkan dengan menentukan tindakan-tindakan pada masa yang akan datang. Strategi ini pada hakikatnya adalah suatu interpretative planning yang dibuat dengan memperhitungkan rencana saingan.

Bimbingan ibadah haji merupakan bimbingan dan latihan serangkaian amalan ibadah ketika melaksanakan haji diantaranya; ihram, wukuf, thawaf, sa'i, tahallul, mabit dan melontar jumrah. Umumnya akan berlangsung 8-12 minggu sebelum keberangkatan. Semua informasi yang dibutuhkan untuk pelaksanaan ibadah haji akan diberikan pada saat bimbingan ibadah haji (manasik) yang biasanya dipandu oleh ustad, ustadzah dan muthoeif (pemandu/guide) yang akan membimbing jamaah haji selama melaksanakan ibadahnya. Hal ini dimaksudkan untuk menjadi pedoman jamaah haji dalam melaksankan bimbingan ibadah haji sesuai dengan alur gerak dan tempat kegiatan haji.

Dengan adanya strategi pelayanan prima yang diterapkan di $\mathrm{KBIH}$ diharapkan akan menjadi tolak ukur meningkatkan kualitas pelayanan terhadap jamaah baik kualitas secara rohani dan jasmani. Secara rohani jamaah mampu melaksanakan ibadah haji dengan khusyu' dengan gelar haji mabrur, adapun kualitas secara jasamani yaitu jamaah mendapatkan pelayanan yang baik dari mulai pembinaan manasik haji, pemberangkatan, perpulang haji serta pascahaji.

Penelitian bertujuan untuk mengetahui strategi pelayanan prima KBIH Maqdis dalam membuat strategi serta langkah-langkah yang tepat untuk calon jamaah dalam meningkatkan kualitas bimbingan ibadah haji diantaranya: pertama, untuk mengetahui program KBIH Maqdis yang ditawarkan kepada calon jamaah haji.Kedua, untuk mengetahui langkah pelaksanaan calon jamaah haji $\mathrm{KBIH}$ Maqdis. Ketiga, untuk mengetahui bentuk pelayanan yang ditawarkan KBIH Maqdis terhadap calon jamaah haji dalam meniingkatkan kualitas ibadah.

\section{LANDASAN TEORITIS}

Strategi berasal dari kata Yunani "strategos" dengan akar kata "stratos" dan "ag". Stratos berarti militer dan ag berarti memimpin. Pada awalnya strategi diartikan generalship, sesuatu yang dilakukan oleh para jendral dalam memenangkan peperangan.

Hayes dan Wheel Wright mengemukakan, bahwa strategi mengandung arti semua kegiatan yang ada dalam lingkup perusahaan, termasuk di dalamnya pengalokasian semua sumber daya yang dimiliki perusahaan (Rangkuti, 2006:56).

Dalam Irmayanti Hasan (2011:27), Heizer dan Render mengungkapkan strategi adalah rencana tindakan organisasi untuk mencapai misinya. Setiap wilayah fungsional mempunyai strategi untuk mencapai misinya dan membantu organisasi mencapai misi keseluruhan.

Perencanaan secara ringkas berarti "Suatu rangkaian proses kegiatan menyiapkan dan menentukan seperangkat keputusan mengeni apa yang 
diharapkan terjadi dan apa yang akan dilakukan (Kusnawan, 2010:902).

Tujuan strategi menurut pandangan Joh. M. Bryson dalam Siti Bilqis (2016:21) adalah untuk menyiapkan organisasi terhadap berbagai ancaman dan peluang eksternal yang mungkin membutuhkan tanggapan dimasa datang yang dapat digunakan. Dengan demikian tujuan dari strategi adalah mempersiapkan organisasi tanggapan secara efektif kepada dunia luar sebelum muncul krisis.Segala tindakan harus diambil ketika tindakan ini diidentifikasi dan bermanfaat serta memiliki tujuan.

Dalam Kamus Besar Bahasa Indonesia (Daryanto, dkk.,2014:107), menyatakan pelayanan adalah usaha melayani kebutuhan orang lain. Pelayanan pada dasarnya merupakan kegiatan yang ditawarkan kepada konsumen atau pelanggan, yang bersifat tidak berwujud dan tiak dapat dimiliki.

Menurut A.S Moenir (2008:17) mengemukakan bahwa pelayanan adalah proses pemenuhan kebutuhan melalui aktivitas orang lain secara langsung. Dengan demikian pelayanan dapat dikatakan sebagai kegiatan yang membentuk suatu proses. Proses pelayanan yang berlangsung secara terus-menerus dan berkesinambungan, meliputi seluruh aspek dalam kehidupan.

Selanjutnya menurut Daviddow dan Uttal dalam (Sahya Anggara, 2012: 568) dikemukakan, pelayanan merupakan aktifitas atau manfaat yang ditawarkan oleh organisasi atau perseorangan kepada pelanggan/ konsumen yang sifatnya tidak berwujud dan tidak dimiliki.

Adapun Gronroos, mengungkapkan bahwa pelayanan merupakan serangkaian aktivitas yang tidak kasat mata, sebagai sebab akibat karena adanya interaksi antara pelanggan dengan petugas pelayanan untuk memenuhi kebutuhan pelanggan (Ratminto dan Atik, 2014:2).

Pada hakikatnya pelayanan prima bukanlah istilah baru dalam dunia kerja, baik itu yang bersifat profit maupun nonprofit. Telah kita ketahui bahwa bentuk dari pelayanan prima meliputi ramah, senyum, sopan, cepat, tepat, terbuka serta tanggungjawab.Hal ini tidak terlepas dari tiga komponen peting pelayanan prima yakni adanya attitude, skill dan knowledge.

Pelayanan prima atau pelayanan istimewa (excellent service), disebut sangat istimewa atau terbaik karena sesuai dengan standar pelayanan yang berlaku serta dimiliki oleh instansi pemberi pelayanan.Hakekat pelayanan publik merupakan pemberian pelayanan prima kepada masyarakat yang merupakan perwujudan kewajiban aparatur pemerintah sebagai abdi masyarakat.

Pelayanan prima adalah pelayanan yang memenuhi kebutuhan praktis (practical needs) dan kebutuhan emosional (emotional needs) pelanggan (Rahmayanty, 2013:18). Dengan demikian, pelayanan prima adalah pelayanan yang sangat baik dan melampui harapan pelanggan. Pada mulanya pelanggan memiliki harapan sederhana terhadap perusahaan yang bersifat standar dan umum. Namun pada kenyatannya perusahaan tersebut memberikan pelayanan yang sangat baik dan tak terduga oleh pelanggan.

Dalam upaya menerapkan pelayanan prima kepada para pelanggan, 
beberapa poin yang harus diperhatikan dan dilaksanakan, salah satunya dengan menjalankan konsep A6 (Barata: 2003:30). Pelayanan prima berdasarkan konsep A6 yaitu, sebagai berikut: pertama, kemampuan (ability), kedua sikap (attitude), ketiga penampilan (appreance), keempat perhatian (attention), kelima tindakan (action), keenam tanggung jawab (accountability).

Istilah pelayanan prima, berasal dari era reformasi di bidang pelayanan publik.Kepuasan pelanggan menjadi orientasi mutlak dalam gerakan ini. David Osborne dan Ted Gabler (Daryanto\&Ismanto, 2014:112), dikemukakan bahwa pengembangan organisasi bermuara dari terwujudnya a smaller, better, faster and chaepter government.Dari pernyataan tersebut mengandung makna bahwa empat hal yang menjadi prioritas yang menjadikan aparatur sebagai pusat garapan.

Oleh karena itu untuk mengetahui indikator sebuah pelayanan dianggap prima, dapat dimulai menguraikan lima prinsip dasar pelayanan prima, yaitu mengutamakan pelanggan, sistem yang efektif, melayani dengan hati, perbaikan yang berkelanjutan serta memberdayakan pelanggan.

Lima hal pokok yang harus diperhatikan dalam merancang pemberian pelayanan prima, yaitu; pertama regulasi layanan (service regulation), kedua fasilitasfasilitas layanan (service facilities), ketiga peranan tim pengarah (advisory team), keempat mudah-murah-cepat-manfaat (simple- cheap-fast-benefit), kelima budaya pemberian pelayanan.

Tujuan dari pelayanan prima adalah memberikan pelayanan yang dapat memenuhi dan memuaskan pelanggan atau masyarakat serta memberikan fokus pelayanan kepada pelanggan. Pelayanan prima dalam wilayah publik didasarkan pada kesadaran bahwa pelayanan merupakan pemberdayaan.

Selain itu, pelayanan prima merupakan upaya mempertahankan pelanggan agar tetap loyal untuk menggunakan produk barang atau jasa yang ditawarkan (Rahmayanty, 2013:13). Sehingga mencegah pembelotan dan membangun kesetiaan pelanggan atau customer loyality. Berpalingnya pelanggan disebabkan karena kesalahan dalam pemberian pelayanan begitupun dengan sistem perusahaan/organisasi dalam memberikan pelayanan kepada pelanggan.

Pelayanan prima akan bermanfaat bagi upaya peningkatan kualitas pelayanan pemerintah kepada masyarakat sebagai pelanggan atau konsumen seklaigus sebagai acuan pengembangan penyusunan standar pelayanan. Penyedia layanan, pelanggan atau stakebolder dalam program pelayanan akan mempunyai acuan mengenai bentuk, alasan, waktu, tempat da proses pelayanan yang seharusnya.

Bagi perusahaan atau organisasi profit, pelayanan prima merupakan hal yang sangat penting, hal ini dikarenakan kelangsungan hidup perusahaan atau organisasi tersebut dipengaruhi oleh pelayanan prima yang diberikan kepada pelanggan atau konsumen.

Sehingga Endar Sugiarto dalam Daryanto dan Ismanto (2014:131), mengemukakan bahwa falsafah pelayanan prima dalam dunia bisnis, pada hakikatnya pelanggan tidak membeli produk melainkan membeli pelayanan. 
Menurut American Society for Quality Control, kualitas adalah keseluruhan dari ciri-ciri dan karakteristik-karakteristik dari suatu produk/jasa dalam kemampuannya untuk memenuhi kebutuhan-kebutuhan yang telah ditentukan atau bersifat laten, dan dengan kata lain kualitas suatu produk/ jasa adalah sejauh mnaa produk/jasa memenuhi spesifikasi-spesifikasinya (Ririn\&Mastuti, 2011:103).

Kualitas sebagai suatu kondisi dinamis yang berhubungan dengan produk, jasa, manusia, proses dan lingkungan yang memenuhi atau melebihi harapan. Kualitas merupakan perwujudan atau gambaran hasil-hasil yang mempertemukan kebutuhan-kebutuan dari pelanggan serta memberikan kepuasan (Rewansyah, 2011:72).Sehingga dapat disimpulkan bahwa kualitas sebagai keistimewaan yang artinya bebas dari kekurangan.

Kualitas pelayanan sebagai tingkat keunggulan yang diharapakan, dan pengendalian atas tingkat keunggulan yang diharapkan, dan pengendalian atas tingkat keunggulan tersebut guna memenuhi tuntutan dan kepuasan pelanggan.

Adapun untuk mengukur berkualitas atau tidaknya suatu lembaga atau perusahaan bahkan jamaah perlu adanya indikator-indikator tertentu. Namun indikator kualitas dan standar pelayanan merupakan indikator yang paling sulit diukur, karena menyangkut pertimbangan yang sifatnya subjektif. Penggunaan indikator kualitas dan standar pelayanan harus dilakukan secara hati-hati karena jika terlalu menekankan indikator ini justru dapat menyebabkan kontra produktif.

Pengukuran kualitas pada dasarnya bersifat relatif tergantung pada ciri-ciri yang digunakan untuk menentukan ciri-ciri dan spesifikasi. Dengan demikian kualitas memiliki delapan dimensi pengukuran sebagai berikut: pertama kinerja (performance), merujuk pada kinerja yang meliputi karakter produk inti yaitu merek, atribut-atribut yang dapat diukur dan aspek kinerja individu.

Kedua keragaman produk (features), keanekaragaman produk dapat berupa penambahan produk inti sebagai penambah nilai suatu produk. Keragaman produk biasanya diukur secara subjektif oleh pelanggan. Sehingga perkembangan kualitas produk bisa berkembang serta menuntut karakter fleksibelitas agar dapat memenuhi permintaan pasar.

Ketiga keandalan (reliability), yaitu mengantisipasi suatu produk jika tidak berfungsi, sehingga perlukan keandalan untuk memelihara produk. Keempat kesesuaian (comformance), kesesuaian barang merupakan kesesuaian barang dengan standar dalam industrinya. Diukur dengan tingkat akurasi waktu penyelesaian, termasuk perhitungan kesalahan serta keterlambatan yang tidak bisa diantisipasi.

Kelima ketahanan (durability), ukuran suatu produk meliputi teknis dan ekonomis. Keenam kemampuan pelayanan (serviceability), meliputi kecepatan, kompetensi, kegunaan serta kemudahan produk untuk diperbaiki. Dengan demikian, dimensi ini menunjukan bahwa pelanggan memperhatikan penuruan kualitas, jadwal pelayanan yang diberikan, kenyaman komunikais dengan staf, serta frekuensi perbaikan pelayanan.

Ketujuh estetika (esthetics), dimensi ini merupakan penilaian dan refleksi 
pelanggan terhadap suatu produk. Dengan demikian pengukuran kualitas dimensi estetika sangat subjektif. Kedelapan kualitas yang dipersepsikan (perceived quality), dimensi ini sangat menekankan pada produk yang memiliki merek, sehingga dengan mudah pelanggan dapat mempersepsikan kualitas produk tersebut.

Bimbingan merupakan terjemahan dari "guidance" yang berasal dari bahasa Inggris. Secara harfiah istilah "guidance" dan akar kata "guide" berarti mengarahkan, memandu, mnegelola dan menyetir. Frank W. Miller dalam Lilis Satriah (2016:37) mengemukakan bahwa bimbingan merupakan proses bantuan terhadap individu untuk mencapai pemahaman diri dan pengarahan diri yang dibutuhkan bagi penyesuaian diri secara baik dan maksimum di sekolah, keluarga dan masyarakat.

Menurut Dewa Kentut Sukardi, bimbingan adalah suatu proses pemberian bantuan yang terus menerus dan sistematis dari pembimbing kepada yang dibimbing agar tercapai kemandirian dalam pemahaman diri, penerimaan diri, pengarahan diri dan perwujudan diri dalam mencapai tingkat perkembangan yang optimal dan penyesuaian diri dengan lingkungnya (Satriah, 2016:15)

Adapun Peters dan Shertzer (Willis, 2014:14) mengemukakan definisi bimbingan (guidance) sebagai berikut: "Guidance, as used bere and thorught this book is defined simply a the process of helping the individual to understand himself and his world so that be can utilize his potentialities."

Dari definisi tersebut menjelaskan pengertian bimbingan adalah proses bantuan terhadap individu agar ia memahami dirinya dan dunianya, sehinga ia dapat memanfaatkan seluruh potensinya. Sehingga dari definisi tersebut dapat

diketahui karaktersitik bimbingan (guidance) adalah sebagai berikut: pertama, bimbingan merupakan upaya yang bersifat preventative, kedua bimbingan dapat diberikan secara individual dan kelompok, ketiga bimbingan dapat dilakukan oleh guru, pemimpin, ketua-ketua organisasi, dan sebagainya.

Adapun yang dimaksud bimbingan dalam penelitian ini adalah berkaitan dengan bimbingan ibadah haji yang dilakukan oleh pihak penyelenggara haji kepada jamaahnya.Bimbingan ibadah haji merupakan pembinaan jamaah prahaji. Oleh karena itu, yang dimaksud dengan kualitas bimbingan ibadah adalah pembinaan ibadah haji yang memberikan kepuasan kepada jamaah yang dimulai dari pelaksanaan manasik haji sampai pelaksanaan ibadah haji.

\section{HASIL DAN PEMBAHASAN}

Pada awalnya sebelum menjadi KBIH, Maqdis merupakan yayasan al-Quran yang mendakwahkan al-Qur'an. Pada tahun 90-an yayasan al-Qur'an ini diberi nama Maqab (markas al-Qur'an Bandung). Kemudian pada tahun 2000 diubah menjadi Maqdis (ma'had qur'an dirosah Islamiah) yang merupakan pesantren al-Qur'an dan pendidikan Islam. Pada tahun 2001, tuntutan dari masyarakat serta kultur di Indonesia ketika pelaksanaan ibadah haji membutuhkan pembimbing haji, maka dibentuklah KBIH untuk melayani calon jamaah haji yang didirikan oleh Dr.K.H. Saiful Islam Mubarak, Lc.,M.Ag., yang merupakan dewan pimpinan Maqdis saat ini. 
KBIH Maqdis merupakan salah satu lembaga yang bergerak dalam bidang jasa yang membantu pemerintah dalam penyelenggaraan ibadah haji dari $45 \mathrm{KBIH}$ yang berada di Kota Bandung. KBIH MAQDIS berada di bawah naungan Yayasan Maqdis menjalankan aktifitasnya berdasarkan Surat Keputusan (SK) Kepala Kantor Wilayah Kementerian Agama Propinsi Jawa Barat Nomor : 486.15 TAHUN 2015 tertanggal 18 Juni 2015. Kantor pusat KBIH Maqdis beralamat di Metro Indah Mall Blok D-20 Jl.Soekarno Hatta No.590 Sekejati, Buah Batu, Kota Bandung 40286.

Perkembangan kuota jamaah haji di KBIH Maqdis dari tahun ke tahun mengalami kenaikan yang signifikan.Khususnya pada tahun 2017 peningkatan jamaah haji yang bergabung dengan KBIH Maqdis sangat pesat.Adapun jumlah jamaah haji pada tahun ini yaitu 111 orang. Pada tahun ini pula KBIH Maqdis pertam kalinya akan memberangkatkan jamaah haji dengan jumlah yang cukup banyak. Sehingga menjadi keistimewaan bagi KBIH Maqdis untuk membantu calon jamaah haji.

Hasil penelitian ini menemukan tentang konsep pelayanan prima $\mathrm{KBIH}$ Maqdis, rancangan pemberian pelayanan KBIH Maqdis dan bentuk pelayanan KBIH Maqdis dalam meningkatkan kualitas bimbingan ibadah haji.

\section{Konsep Pelayanan Prima KBIH Maqdis}

Berdasarkan hasil wawancara yang dilakukan dengan Pak Nunu Nurarifin selaku sekretaris KBIH Maqdis yang dilaksankan pada tanggal 24 Mei 2017, ditemukan hal mendasar pelayanan prima yang harus dimiliki karyawan KBIH Maqdis yaitu: pertama, rasa memiliki terhadap KBIH Maqdis. Kedua, rasa memiliki terhadap pekerjaan. Ketiga, loyalitas yang tinggi terhadap pekerjaan. Keempat, ingin menjaga nama baik KBIH Maqdis.

Dengan demikian, konsep pelayanan prima akan tercipta dalam pemberian pelayanan oleh karyawan KBIH Maqdis kepada jamaah haji. Dalam upaya menerapkan pelayanan prima kepada para pelanggan, beberapa poin yang harus diperhatikan dan dilaksanakan, salah satunya dengan menjalankan konsep A6 (Barata: 2003:30).

Konsep pelayanan prima yang diterapkan di KBIH Maqdis sebagai berikut: pertama, kemampuan(ability), karyawan KBIH Maqdis memiliki kemampuan dan ahli dalam bidangnya. Salah satunya yaitu KBIH Maqdis memiliki pembimbing haji yang profesional dalam artian pembimbing haji yang berilmu, berpengalaman serta bertanggungjawab. Begitupun dengan karyawan $\mathrm{KBIH}$ Maqdis lainnya memiliki wawasan pengetahuan dan keterampilan yang sesuai dengan bidang pekerjaannya.

Berdasarkan wawancara dengan Pak Nunu Nurarifin pada tanggal 24 Mei 2017, menyatakan bahwa semua karyawan KBIH Maqdis telah teruji kemampuan sesuai bidangnya. Terlebih KBIH Maqdis sangat memperhatikan para pembimbing calon jamaah haji. Ada beberapa indikator penting dalam perekrutan calon pembimbing haji. Bagi KBIH Maqdis memberikan pelayanan merupakan hal yang penting bagi jamaah dengan harapan kemabruran jamaah haji setelah 
perpulangan dari tanah suci sehingga tak terlepas dari peran serta para pembimbing haji yang baik dalam keilmuan dan pengalamannya.

Kedua, sikap(attitude), sikap merupakan poin pertama yang diperhatikan KBIH Maqdis terhadap karywannya. Dengan menciptakan sikap yang baik maka akan terjalin pula hubungan yang baik dengan calon jamaah yang akan bergabung dengan KBIH Maqdis. Sehingga seluruh karyawan KBIH Maqdis memiliki akhlakul karimah.

Akhlakul karimah merupakan sikap yang tercermin dari karyawan $\mathrm{KBIH}$ Maqdis. Rasa memiliki terhadap $\mathrm{KBIH}$ sangat tinggi, kebanggaan dan loyalitas karyawan terhadap pekerjaannya yang tercermin dari kehadiran karyawan yang selalu tepat waktu, selalu menjaga nama baik KBIH Maqdis dengan memberikan pelayanan yang baik serta sopan santun. Berdasarkan wawancara bersama Pak Nunu Nurarifin, bahwa sikap merupakan indikator paling penting yang harus dimiliki oleh setiap karyawan KBIH Maqdis, meskipun seseorang mumpuni dalam suatu bidang namun memiliki sikap yang kurang baik maka KBIH tak menghiraukan itu semua. Oleh karena itu KBIH Maqdis sangat selektif dalam memperhatikan sikap para karyawannya.

Ketiga, penampilan (appreance), selain memperhatikan sikap yang berakhlakul karimah, karywan KBIH Maqdis pun memiliki penampilan yang rapi dalam memberikan pelayanan kepada jamaah. Untuk karyawan perempuan KBIH Maqdis memakai pakaian muslim syar'i, sedangkan karyawan laki-laki KBIH Maqdis memakai pakaian rapi. Dalam memperhatikan penampilan karyawan KBIH Maqdis memiliki seragam yang dipakai pada hari-hari tertentu.

Keempat, perhatian(attention), karyawan KBIH Maqdis memperhatikan setiap kebutuhan jamaah haji juga terhadap saran atau kritik dari calon jamaah. Sikap yang ditunjukkan kepada calon jamaah karyawan KBIH Maqdis membantu calon jamaah haji dalam melengkapi dokumen pemberangkatan ibadah haji, membantu pemeriksaan kesehatan tahap satu dan tahap dua selain memenuhi kebutuhan jamaah dengan memberikan pehatian dalam pelayanannya juga membimbing jamaah belajar mengkaji Al-Qur'an.

Berdasarkan wawancara bersama Pak Nunu Nurarifin, menyatakan bahwa KBIH Maqdis membimbing jamaah haji dalam mengkaji Al-Qur'an, karena selain bimbingan teori dan praktek jamaah haji juga ada jadwal bimbingan mentadaburi al-Qur'an yang dimulai dengan program dasar melancarkan bacaan Al-Qur'an, memperbaiki bacaan Al-Qur'an serta pendalaman ilmu Al-Qur'an. Hal ini yang menjadi pembeda KBIH Maqdis dengan KBIH lainnya tutur beliau.

Kelima, tindakan(action), KBIH Maqdis cepat tanggap dalam memenuhi kebutuhan pelanggan, baik itu pelanggan internal maupun kepada pelanggan eksternal. Selalu berusaha meningkatkan perbaikan mutu dengan cepat tepat dalam melayani saran dan kritik jamaah. Berdasarkan wawancara bersama Pak Nunu Nurarifin, KBIH Maqdis selalu berusaha memberikan pelayanan terbaik kepada jamaahnya apapun itu selama berkaitan dengan pelayanan jamaah haji.

Keenam, tanggung jawab (accountability), karyawan KBIH Maqdis 
memiliki tanggung jawab yang tinggi dalam memberikan pelayanan terhadap jamaah haji. Mengantisipasi dalam pemberian pelayanan kepada jamaah. Bagi sebuah perusahaan atau organisasi pelayanan prima bertujuan terhadap kelangsungan hidup perusahaan. Apabila pelayanan yang diberikan tidak memuaskan tentu saja akan mengecewakan pelanggannya.

Dengan demikian konsep pelayanan yang diberikan KBIH Maqdis terhadap calon jamaah dapat memberikan kesan yang baik. Sehingga tetap menjaga dan merawat (maintance) agar pelanggan merasa diperhatikan dan dipentingkan semua kebutuhannya atau keinginannya. Hal ini yang harus diperhatikan dalam setiap pemberian pelayanan kepada konsumen. Karena pelayanan dengan kualitas tinggi akan selalu mengikuti serta memantau perkembangan kebutuhan pelanggan secara konsisten dan akurat (Rahmayanty, 2013:13).

\section{Rancangan Pemberian Pelayanan}

Pelayanan merupakan proses dalam memenuhi kebutuhan pelanggan yang menyebabkan interaksi antara pelanggan internal dan pelanggan eksternal. Setiap perusahaan menyusun dan mengembangkan jasa pelayanan kepada pelanggan mencakup sistem, aturan, keputusan, prosedur dan tatacara pelayanan dan keluhan supaya memudahkan dalam standar pelaksanan pelayanan serta berguna menyampaikan produk dan atau jasa perusahaan.

Standar pelayanan terlihat jelas dari dasar hukum, persyaratan pelayanan, prosedur pelayanan, waktu pelayanan, biaya serta proses penagduan, sehingga petugas pelayanan memahami tugas dan kewajibannya dalam memberikan pelayanan.

Berikut rancangan pemberian pelayanan KBIH Maqdis, diantaranya: pertama, regulasi layanan SOP (Standard Operating Procedures) atau standar pelayanan merupakan acuan dasar aturan di setiap perusahaan. Dalam SOP yang dibuat setiap perusahaan maka akan terlihat dengan jelas dasar hukum, persyaratan pelayanan, prosedur pelayanan, waktu pelayanan, biaya serta proses pengaduan, sehingga petuggas pelayanan memahami apa yang harus mereka lakukan dan memberikan pelayanan (Rahmayanty, 2013:67)

SOP dibuat oleh perusahaan untuk mnegindari tejadinya variasi dalam proses pelaksanaan kegiatan oleh pegawai yang akan mengganggu kinerja organisasi secara keseluruhan. Namun, hasil temuan penulis pada lembaga sosial pelayanan bimbingan ibadah haji KBIH Maqdis mengenai regulasi pelayanan belum dilaksanakan secara optimal, karena prosedur pelayanan belum didokumentasikan secara tertulis. Hal ini memungkinkan menyebabkan kesulitan bagi karyawan dalam melaksanakan semua kegiatan pelayanan di KBIH Maqdis. Sehingga monitoring dan evaluasi kinerja pelayanan tidak terlaksana dengan baik.

Kedua, fasilitas-fasilitas layanan, sebagai lembaga sosial yang bergerak di bidang pelayanan bimbingan ibadah haji $\mathrm{KBH}$ Maqdis memiliki sarana dan prasarana dalam menunjang kebutuhan jamaah. Berdasarkan hasil wawancara dan penelitian, maka sarana yang ada di KBIH Maqdis sebagai berikut: pertama kantor/ kesekretariatan, kedua ruang kerja, ketiga ruang rapat, keempat ruang tunggu, kelima 
Pusti Lestari, Dadang Kuswana, \& Yuliani

telepon, keenam komputer, ketujuh kamar mandi, kedelapan tempat parkir.

Namun dari hasil penelitian kantor kesektretariatan KBIH Maqdis kurang luas dikarenakan bersatu dengan travel Maqdis sehingga bimbingan manasik haji selalu dilakukan diluar baik itu dalam pemberian materi ataupun praktek. Ruang kerja KBIH Maqdis tidak bersekat jadi semua karyawan yang bekerja berkumpul dalam satu ruangan, tempat parkir kurang luas sehingga akan menyulitkan calon jamaah untuk parkir.

Berdasarkan hasil wawancara dengan Pak Nunu Nurarifin, mengatakan bahwa memang KBIH Maqdis belum memiliki kantor sendiri yang memiliki ruangan yang luas untuk melakukna bimbingan baik teori maupun praktek. Namun meskipun begitu tidak menjadi kendala bagi pihak KBIH Maqdis dalam memberikan pelayanan prima kepada jamaah haji meskipun bimbingan dilakukan di luar kantor.

Ketiga, peranan tim pengarah merupakan penanggung jawab tertinggi manajemen yaitu pimpinan. Peranan tim pengarah KBIH menjadi tanggung jawab ketua KBIH Maqdis. Peranan tim pengarah KBIH Maqdis diantaranya: pertama, perencanaan dan persiapan KBIH Maqdis belum terlaksana secara optimal, karena prosedur standar pelayanan KBIH Maqdis belum di dokumentasikan secara tertulis.

Kedua, monitoring atau pengawasan dilakukan dengan baik oleh tim pengarah ketua KBIH. Hal ini terlihat dari kegiatan sebelum mulai bekerja seluruh karyawan berkumpul bersama kemudian melaksanakan shalat duha dan membaca al-Qur'an. Kemudian selalu di adakan tausiyah khusus untuk seluruh karyawan KBIH Maqdis secara berkala. Ketiga, KBIH Maqdis memberikan pelatihan dan pendidikan secara berkala terhadap karyawannya. KBIH Maqdis memantau perkembangan pembimbing haji dengan memperhatikan sertifikasi bagi pembimbingnya tersebut.

Keempat, KBIH Maqdis selalu memberikan reward kepada karyawan dengan ketentuan-ketentuan tertentu, misal dalam hal pelayanan serta perekrutan calon jamaah haji. Kelima, ketua KBIH mempercayakan semua kegiatan kepada karyawannya, sehingga kemandirian karyawan tercipta dengan pengawasan ketua KBIH. Keenam, menjalin silaturahmi dengan calon jamaah haji serta alumni jamaah haji Maqdis dengan baik. Diadakannya reuni secara berkala dalam rangka mempererat tali silaturami dengan jamaah.

Keempat, budaya pemberian pelayanan merupakan kebiasaan pelayanan yang diberikan kepada pelanggan. Berikut ini temuan penulis mengenai budaya pemberian pelayanan KBIH Maqdis diantaranya: pertama, self awarnes temuan penulis dari hasil wawancara dan observasi para karyawan KBIH Maqdis memiliki kesadaran yang tinggi dalam memberikan pelayanan kepada calon jamaah. Hal ini terlihat dari keramahan karyawan ketika menerima tamu, dan selalu membantu dengan sebisa mungkin serta memberikan perhatian penuh.

Kedua, anthusiasm karyawan KBIH Maqdis sangat antusias terhadap tamu yang datang berkunjung ke KBIH Maqdis, baik itu calon jamaah haji yang akan 
mendaftar, maupun masyarakat yang berkeinginna belajar al-Qur'an di Maqdis.

Ketiga, reform KBIH Maqdis selalu memperbaiki dan meningkatkan kinerja pelayanan dengan melakukan perbaikan mutu pelayanan dalam setiap kegiatan yang dilakukan. Pertumbuhan dan perkembangan jamaah haji menjadi tolak ukur KBIH Maqdis. Testimoni jamaah haji terhadap kegiatan yang telah dilakukan KBIH Maqdis menjadi evaluasi dasar mengenai saran dan kritik terhadap KBIH. Selanjutnya evaluasi dilakukan dengan semua karyawan KBIH yang terlibat.

Pertumbuhan dan perkembangan jamaah haji KBIH Maqdis merupakan proses dari peningkatan kinerja pelayanan yang diberikan kepada jamaah haji. Hal ini dapat dilihat dari grafik peertumbuhan dan perkembangan jamaah haji KBIH Maqdis dari tahun ke tahun mengalami peningkatanyang sanagat baik.

Keempat, value KBIH Maqdis selalu menjalin silaturahmi yang baik dengan para calon jamaah haji serta alumni jamaah KBIH Maqdis. Hal ini menjadi nilai tambah tersendiri bagi KBIH selain menjalin persaudaraan juga menjaga loyalitas para jamaah terhadap KBIH.

Kelima, impressive KBIH Maqdis memberikan pelayanan yang baik, meninggalkan kesan yang tidak berlebihan. Berdasarkan hasil temuan dilapangan Pelayanan yang diberikan KBIH Maqdis tidak meninggalkan kesan karena ingin pujian atau kesan yang berlebihan. Namun pelayanan diberikan dengan cepat, tepat dan akurat terhadap kebutuhan jamaah haji. Serta penampilan yang sopan santun tercermin dari setiap karyawannya.

Keenam, care KBIH Maqdis memberikan perhatian dan kepedulian terhadap jamaah dengan adanya bimbingan al-Qu'ran secara intensif, membantu jamaah dalam mempersiapkan kelengkapan dokumen haji, membantu jamaah dalam pemeriksaan keseharian tahap satu dan tahap dua, serta menjaga komunikasi yang baik dengan alumni jamaah haji KBIH Maqdis.

Ketujuh, evaluation KBIH Maqdis selalu melakukan evaluasi setelah kegiatan dilakukan missal dalam kegiatan manasik haji baik teori maupun praktek serta ketika pelaksanaan haji di tanah suci. Evaluasi kerja dilakukan setiap sebulan sekali.

Dengan demikian pentingnya kesadaran masing-masing pribadi individu serta antusias terhadap jamaah kemudian perbaikan kinerja pelayanan sehingga memberikan nilai tambah tersendiri bagi KBIH Maqdis yang menimbulkan kesan yang baik dan memperhatikan setiap kegiatan yang telah dilaksanakan.

\section{Kualitas Bimbingan Ibadah Haji}

Pembimbing ibadah haji, pembimbing ibadah haji merupakan sumber daya manusia yang sangat penting agar pelaksanaan ibadah haji berjalan dengan lancar.Pembimbing haji adalah orang yang menguasai pengetahuan manasik haji dan telah mengikuti sertifikasi pembimbing haji yang dilaksanakan oleh direktorat penyelenggara haji dan umroh.

Dari hasil temuan penulis KBIH Maqdis selektif dalam menentukan pembimbing jamaah haji selain pembimbing haji memenuhi syarat dengan adanya tanda sertifikasi juga ada beberapa ketentuan KBIH Maqdis dalam perekrutan pembimbing ibadah haji diantaranya: pertama, menguasai fiqh manasik dengan 
benar dan mampu mempraktikkannya. Kedua, berilmu, berpengalaman dan bertanggungjawab. Ketiga, satu misi dengan KBIH Maqdis dengan haji tarwiyah.

Keempat, menguasai bahasa yang dibutuhkan. Kelima, mampu membimbing. Keenam, berakhlakul karimah. Ketujuh, berorientasi pada pengabdian.

Berdasarkan hasil temuan penulis dari KBIH Maqdis mengenai materi bimbingan manasik haji sebagai berikut: pertama pengantar, sekilas tentang Maqdis pelaksanaan haji Indonesia; pelaksanaan haji Indonesia; persiapan yang harus dilakukan; Perbedaan jamaah haji Maqdis.

Kedua, pengenalan tempat ibadah haji; pengenalan kota Mekkah; pengenalan Masjidil Haram; pengenalan Ka'bah dan Safa Marwah; pengenalan Maktab; pengenalan makanan di Mekkah; pengenalan Mina; Arafah dan Muzdalifah.

Ketiga, Manasik haji; kewajiban haji; tatacara bepergian; Ihram (Al ihram, sebelum berihram, tempat mulai berihram). Keempat, larangan-larangan ihram. Kelima, macam-macam ibadah haji; Haji Tamattu; Qiran; Ifrad; sebelum memasuki hari Tarwiyah. Keenam, umrah dan pembahasannya; Thowaf Umrah; catatan penting saat Thowaf; Sa'i umrah; Bukit Marwa.

Ketujuh, haji dan pembahasannya; rukun haji dan wajib haji; tanggal 8 Dzulhijjah; tanggal 9 Dzulhijjah; kekeliruan yang sudah menyebar; Muzdalifah; jamaah tiba di Mina; tanggal 10 Dzulhijjah; melempar Jamarat; Thowaf ifadhah; Hari-hari Tasyrik; Thowaf Wada'.

Kedelapan, hukum-hukum khusus untuk mu'minat. Kesembilan, tata cara ziarah Masjid Nabawi. Kesepulub, do'a-doa pilihan. Kesebelas, tempat- tempat bersejarah dan tempat tinggal di Madinah; tempat-tempat bersejarah di Mekkah; Kota Madinah; Masjid Nabawi; tempat-tempat bersejarah di Nabawi. Keduabelas, tempat-tempat tinggal di Madinah; perjalanan haji Maqdis; praktek lapangan; peview seluruh materi manasik; test kesehatan.

Temuan penulis mengenai pemilihan materi bimbingan ibadah haji $\mathrm{KBIH}$ Maqdis sudah dilaksanakan dengan baik. Materi bimbingan ibadah haji KBIH Maqdis bisa berubah disesuaikan dengan kebutuhan tanpa mengurangi nilainya. Penyampaian materi baik teori maupun praktek bimbingan dilakukan 15 kali pertemuan dengan durasi pertemuan 2,5 jam.

\section{PENUTUP}

Berdasarkan data yang diperoleh dari hasil analisis, maka dapat ditarik kesimpulan strategi pelayanan prima kelompok bimbingan ibadah haji terhadap calon jamaah dalam meningkatkan kualitas bimbingan ibadah haji di KBIH Maqdis Bandung, yaitu:

KBIH Maqdis merupakan salah satu lembaga penyelenggara bimbingan ibadah haji yang berada di Kota Bandung yang menjadi pembeda KBIH Maqdis dengan lembaga penyelenggara bimbingan ibadah haji lainnya yaitu adanya kajian intesif mentadaburi al-Qur'an. Pertama, konsep pelayanan prima KBIH Maqdis sudah berjalan dengan baik dalam memberikan pelayanan kepada jamaahnya. Kemampuan para karyawan KBIH Maqdis sudah teruji dengan baik contohnya 
pembimbing ibadah haji yang sudah teruji dan berkualitas. Tak hanya itu sikap maupun penampilan karyawan KBIH Maqdis sangat memperhatikan kaidah islam dalam memberikan pelayanan kepada jamaah. Serta tanggungjawab para karyawan dalam bertindak sangat memperhatikan jamaah.

Kedua, rancangan pemberian pelayanan KBIH Maqdis secara keseluruhan belum terlaksana secara optimal, karena KBIH Maqdis belum memilliki prosedur pelayanan secara tertulis yang terangkum dalam SOP. Sehingga menjadi kendala dalam dalam monitoring dan evaluasi kinerja pelayanan.

Ketiga, adapun budaya pemberian pelayanan di KBIH Maqdis sudah terlaksana cukup baik. Seperti halnya kesadaran para karyawan KBIH Maqdis dalam memberikan pelayanan selalu antusias kepada jamaah haji, serta selalu meningkatkan kinerja pelayanan seperti halnya setiap melakukan kegiatan para jemaah diminta untuk mengisi testimoni. Testimoni ini sebagai upaya evaluasi atas keberlangsungan kegiatan. Sehingga menjadi saran dan kritik bagi karyawan KBIH Maqdis dalam meningkatka kinerja pelayanan.

Keempat, kualitas bimbingan ibadah haji KBIH Maqdis terlihat dari para pembimbing jamaah haji serta materi bimbingan haji. Pembimbing ibadah haji merupakan sumber daya manusia yang sangat penting dalam keberlangsungan sebuah lembaga penyelenggara ibadah haji. Dengan adanya pembimbing ibadah haji yang berkualitas sangat mempengaruhi kenyamanan jamaah haji serta mempunyai nilai tersendiri bagi pihak penyelenggara bimbingan ibadah haji.

Oleh karena itu, KBIH Maqdis sangat selektif dalam merekrut calon pembimbing ibadah haji. Selain pembimbing memiliki pengalaman pergi ke tanah suci serta memiliki tanda bukti sertifikasi haji, pembimbing juga harus mumpuni dalam ilmu fiqh serta satu misi dengan KBIH Maqdis yaitu haji tarwiyah.

Selanjutnya mengenai materi bimbingan ibadah haji KBIH Maqdis, sama halnya dengan KBIH lainnya materi bimbingan ibadah haji secara keseluruhan, namun yang membedakannya di KBIH Maqdis para jamaah melakukan haji tarwiyah terlebih dahulu, serta di tanah suci para jamaah KBIH Maqdis disediakan al-Qur'an untuk lebih dekat dengan al-Qur'an.

Berdasarkan hasil temuan penelitian, maka penulis menyatakan beberapa hal yang dengan harapan dapat memberikan kegunaan dan menjadi masukan bagi KBIH Maqdis dalam hal meningkatkan kualitas pelayanan terhadap jamaah, yaitu: Pertama, KBIH Maqdis hendaknya memiliki SOP secara tertulis agar para karyawan $\mathrm{KBIH}$ Maqdis memiliki acuan standar prosedur pelayanan yang akan diberikan kepada jamaah. Tidak hanya bagi karyawan bagi jamaah sebagai jaminan pelayanan serta bagi KBIH Maqdis sendiri sebagai monitoring dan evaluasi terhadap kinerja pelayanan.

Penelitian yang penulis teliti ini berfokus pada strategi pelayanan prima kelompok bimbingan ibadah haji terhadap calon jamaah dalam meningkatkan kualitas bimbingan ibadah haji agar bisa ditindak lanjuti pelneliti lain mengenai manajemen pelayanan prima lebih komprehensif karena penulis merasa belum sempurna dan masih banyak kekurangan dalam poses penelitian ini. Yayasan 
Pusti Lestari, Dadang Kuswana, \& Yuliani

Maqdis selain memiliki KBIH juga memiliki Pesantren Tahfidz Qur'an sehingga masih terbuka lahan bagi peneliti lebih lanjut.

\section{DAFTAR PUSTAKA}

Ampel,I. (2014). Ibadah Haji, diakses 25 Nopember 2016

http:/ / haji.kemenag.go.id/v2/blog/ahmad-ikhwanuddin/dasar-ibadah-haji

Barata, A. A. (2010). Dasar-Dasar Pelayanan Prima. Jakarta:PT. Elex Kelompok Gramedia.

Daryanto,\& Ismanto. S. (2014 ).Konsumen dan Pelayanan Prima. Yogyakarta: Gava media.

Husni, A. (2013). diakses $29 \quad$ Nopember 2016 http:/ / repository.uinjkt.ac.id/dspace/handle/123456789/32365

Kusnawan, A. (2010). Perencanaan Pendidikan Tinggi Islam. dalam Ilmu Dakwah: Academic Journal for Homiletic Studies. 5(15) 902

Moenir.(2008). Manajemen Pelayanan Umum di Indonesia. Jakarta: PT. Bumi Aksara.

Putuhena, S. M. (2007). Historiagrafi Haji Indonesia. Yogyakarta: LKiS.

Nasrudin, R. (1998). Dienul Islam. Bandung: PT. Al-Ma'arif.

Nurrohmani, A.2006, diakses $29 \quad$ Nopember 2016 http://repository.uinjkt.ac.id/dspace/handle/123456789/24458

Moch. Nur Ikhwan, "Governing Hajj: Politics in Islamic Pilgrimage Services in Indonesia Prior to Reformasi Era”, al-Jami'ah: Journal of Islamic Studies, 46, 1, (2008).

Rahmayanty, N. (2013). Manajemen Pelayanan prima. Yogyakarta: Graha Ilmu.

Rangkuti, A. (2016). Jumlah Jamaah Haji Indonesia Seabad Lebih, diakses 25 Nopember 2016 dari http://haji.kemenag.go.id/v2/blog/affanrangkuti/haji-dalam-angka-jumlah-jemaah-haji-indonesia-dalam-seabadlebih

Rosadi, A. (2011). Sejarah, Perkembangan, dan Pengelolaan Ibadab Haji di Indonesia. Bandung: Cv. Arfino Raya.

Satriah, L. (2016). Panduan Bimbingan Konseling dan Pendidikan. Bandung: CV Mimbar Pustaka.

Solihin, I. (2012).Manajemen Strategik. Bandung: Erlangga.

Sukayat, T. (2016).Manajemen Haji, Umrah, dan Wisata Agama. Bandung: Simbiosa Rekatama Media.

Taufiqurrohman.(2011). Manasik Haji \& Ziarah Spiritual. Malang: UIN Maliki Press.

Yamit, Z. (2010). Manajemen Kualitas Produk dan Jasa. Yogyakarta:

Ekonisia.

Zas, M. (2005). Haji dan Pencerah Jati Diri Muslim. Bandung: Alfabeta. 